Egyptian Journal of Rabbit Science, 26(1): 105 - 119 (2016)

\title{
STUDIES OF SOME SKIN AND ITS COAT CHARACTERISTICS IN RELATION TO FEED ADDITIVES OF GROWING RABBITS
}

\author{
E. A. Taha; Samia, A. Hekal and Naglaa. S. Badawey \\ Department of Wool Production and Technology, Desert Research Center, \\ Cairo, Egypt
}

Sixty growing New Zealand white rabbits aged four weeks were used in this study to assess the effect of age and two feed additives on some fiber traits and skin follicles characteristics. The experiment continued for one month to the age of eight weeks. Rabbits were randomly divided to three groups; the first group was control fed on concentrated pellet, the second group was supplemented with Micronil (1 ml/L of drinking water) as an antimicrobial antifungal compound while the third group was provided with Turbocal forte $(1 \mathrm{ml} / \mathrm{L}$ of drinking water) as a source of minerals and trace elements.

At four, six and eight weeks of age, five rabbits from each group were weighed, skin biopsy was obtained from the right flank of each animal and hair samples were removed by a sharp clipper. Skin samples were examined to study the effect of age and treatments on skin follicles characteristics and fiber diameter.

The results showed that external diameter, internal diameter, fiber diameter of the primary and secondary skin follicles and $S / P$ ratio increased $(P<0.05)$ at six weeks of age. Wall thickness of primary and secondary follicles increased $(P<0.05)$ at eight weeks of age. The prickle factor increased $(P<0.05)$ with age advance. It accounted for 2.27, 4.68 and 4.67 (\%) at four, six and eight weeks, respectively. It seems that there is a critical growth period at the age of six weeks in which the fiber length decreased and the fiber diameter increased.

Micronil supplementation decreased $(P<0.5)$ external diameter, internal diameter and fiber diameter of the primary and secondary skin follicles as well as the wall thickness of the primary follicles. Turbocal forte supplementation decreased $(P<0.05)$ the external diameter and the wall thickness of the primary follicle and the fiber diameter of the secondary follicles. Both types of supplementation increased $(P<0.05)$ the average fiber length compared with the control group.

Keywords: Skin follicles, Histology, Coat fibres, Feed additives, New Zealand White Rabbits 
High quality rabbit skins are used in fur garments and trimming in medical and cosmetic researches. New Zealand White rabbits are the most popular meat producing and pet strain in the world (Oznurlu et al., 2009). Lebas et. al. (1997) stated that the main importers of raw skins are developing countries with the low-cost labour to do the dressing.

Two types of hair follicles can be distinguished in rabbit skin; the primary and the secondary follicles. The primary follicles have a large diameter and rooted deep in the dermis and usually associated with sebaceous and sweet glands and emerges the primary hair fiber. The secondary follicles are smaller in diameter; their roots are superficially located and may have a sebaceous gland but lack a sweet gland and erector pili muscle and emerges secondary hair fibers (Monteiro-Riviere and Stinson, 1998).

Hair fiber growth cycle is a complex event displaying cyclic changes and interactions between dermal papilla and germinal matrix cells. Dermal papilla sends chemical signals to release the germinal matrix cells, which proliferate and elongate the hair shaft and produce an inner root sheath in response to these signals (Stenn and Paus, 2001).

Hair growth is a highly regulated cyclical process. Three distinct phases have been defined for the mammalian cycle: anagen (growing phase), catagen (regressing phase) and telogen (resting phase) (Soma et al., 1998). The longer anagen phase results in longer hair fiber obtained. In Angora rabbit, prolonged growth phase (anagen) of the hair follicle growth cycle which lasts for approximately 14 weeks results in unusual length of Angora hair fiber. While in other rabbit strains, growth phase is shorter and lasts only 5 weeks (Allain, 2007). Paus et al. (1990) and Lanszki et al. (2001) mentioned number of factors that affect growth cycle of the hair such as season of the year, nutrition, age, sex, health and hormonal status of the animal.

Schlolaut (1985) reported that hair yield and characteristics are also affected by nutrition, breed, age, weight, holding system, climate and season of the year. According to Lebas (2000) Supplementation with vitamin E is necessary in rabbit farms that depend on concentrated pellets especially when alfa alfa is not a feeding gradient. Yamani and Stein (1989) reported that vitamin E deficiency was associated with reproduction problems.

Feed additives supplementation is an ordinary procedure in rabbit farms to improve rabbit's performance, increase immunity and enhance the growth rate by providing their requirements of vitamins, minerals and trace elements. Skin and hair disorders in growing female rabbits were reported by Shaw et al. (1974) who reported some clinical signs of $\mathrm{Zn}$ deficiency in the form of achromotrichia and some dermatosis and hair loss in growing female tan 
rabbits. They suggested that these syndromes were caused by an interaction the low zinc intake and biotin, pantothenic acid, folic acid or lysine. Hynd (2000) indicated to specific importance of copper and zinc in the nutrition biochemistry of wool and hair follicles. In contrarily, Anandan et. al. (1998) found no changes in body weight, wool yield, fiber length and diameter of adult German Angora rabbits supplemented with additional zinc and copper for consequent ninety days. The histological characteristics of the skin in the New Zealand White rabbit were suitable for leather industry (Oznurlu et al., 2009).

Therefore, the present work aimed to study the changes in some coat traits and skin follicles characteristics of growing New Zealand white rabbits raised under the semi-arid conditions in the western north of Egypt with concerning the effect of some feed additives those usually used in rabbit farms at this area.

\section{MATERIALS AND METHODS}

Sixty growing New Zealand White rabbits aged four weeks and weighed $(878.67 \pm 39.68 \mathrm{~g})$ were used in this study at Maryout Research Station belongs to Desert Research Centre, $35 \mathrm{~km}$ south west of Alexandria.

Rabbits were randomly divided to three groups $(n=20)$, each group was housed in individual battery of galvanized cages where each cage contained four rabbits to avoid jostle and scramble of animals. Commercial pelleted diet were offered to rabbits ad libitum and fresh water was available to rabbits all the time. All rabbits were kept under the same managerial, hygienic and environmental conditions.

The first group (G1) served as control, fed on commercial pellet of diet. The second group (G2) was supplemented with Micronil $(1 \mathrm{ml} / \mathrm{L}$ of drinking water) as antimicrobial antifungal, antimycotoxins, hepatic-renal tonic and immune stimulator compound. Micronil is consisted of propionic acid, ammonium propionate, sorbitol, potassium, propynil glycol and vitamin E. The third group (G3) was supplemented with Turbocal forte (1 $\mathrm{ml} / \mathrm{L}$ of drinking water) as a source of minerals and trace elements $\left(\mathrm{ZnSO}_{4}\right.$ $100000 \mathrm{mg}, \mathrm{MnSO}_{4} 120000 \mathrm{mg}, \mathrm{FeSO}_{4} 120000 \mathrm{mg}, \mathrm{KI} 1000 \mathrm{mg}, \mathrm{SO}_{4} 85$ $\mathrm{mg}, \mathrm{NaCl} 48000 \mathrm{mg}$ and orthophosphoric acid (85\%) $108000 \mathrm{mg}$ per each $\mathrm{ml}$ of the solution).

Skin biopsy samples were obtained from the right flank region and fixed by immersion in formol calcium (Barker, 1958). After 24 hours, tissues were processed and stained with haematoxylin and Eosin for histological examination (Drury and Wallington, 1980). Histological 
measurements included internal and external wall follicle diameters, follicle wall thickness and fiber diameter. The follicle wall thickness was determined by subtract of the average of internal diameter from the average of external diameter for each follicle. Histological parameters were measured using Image analyzer software (Zen, 2012, Blue edition) and device Carl-Zeiss micro-imaging Gmbh) with lenses 10/0.847 and 40/ 0,65.

Hair samples were taken by sharp clipper from a small area at the right flank as described by Rogers et al. (2006). Five hundred pieces of hair fiber were randomly collected to determine the length and type of hair fibers which divided into coarse and fine according to the method described by Tao (1992). Prickle factor measurement was determined by quantify the percentage of fibers $>30 \mu \mathrm{m}$ in width, these fibers capable of irritate humans when worn next to the skin (Rogers et al., 2006).

Data of the experiment were analyzed by ANOVA a completely randomized designed according to Snedecor and Cochran (1982) by using SAS (2007) program using general linear model (GLM) procedure. Means were significantly separated using Duncan's multiple range tests (Duncan, 1955) were wed for the multiple comparisons.

\section{RESULTS AND DISCUSSION}

External diameter of primary and secondary skin follicle was affected $(\mathrm{P}<0.05)$ by the age of animal and the type of feed additive (Table 1$)$. In the Primary follicles, the external diameter increased noticeably at six and eight weeks of age compared with its value at four weeks of age. Rabbits in G2 and G3 had lower external primary follicle diameter than those of control group. In the secondary follicles, another pattern of the effect of age was found; where the external diameter increased at the age of six weeks then return approximately to its value at four weeks when rabbits approached eight weeks of age (Table 1).

The overall least square mean of external diameter in the secondary follicles of $\mathrm{G} 2$ was lower $(\mathrm{P}<0.05)$ than the other groups.

The internal diameter of the primary and secondary follicles was affected $(\mathrm{P}<0.05)$ by age and feed additives (Table 2$)$. Internal diameter of the primary follicles increased at six weeks of age (by about 33.54\%), then declined to an intermediate value at eight weeks of age. In the secondary follicles, internal diameter increased from four to six weeks of age, and then it decreased to its lowest value at eight weeks of age. 


\section{STUDIES OF SKIN AND ITS COAT CHARACTERISTICS OF RABBITS 109}

Internal diameter of the primary and secondary follicles was lowered $(\mathrm{P}<0.05)$ in $\mathrm{G} 2$ rabbits compared with the other groups. According to Hynd (2000), little evidence implicating $\alpha$-tocopherol (Vitamin E) in follicular

Table 1. Least square means ( \pm S.E.) for external diameter of primary and secondary follicles in the skin of rabbits as affected by feed additives and ages.

\begin{tabular}{|c|c|c|c|c|c|}
\hline \multirow{2}{*}{$\begin{array}{c}\text { Follicle } \\
\text { Type }\end{array}$} & \multirow{2}{*}{$\begin{array}{l}\text { Age in } \\
\text { Weeks }\end{array}$} & \multicolumn{3}{|c|}{ Treatment groups } & \multirow{2}{*}{$\begin{array}{c}\text { Overall } \\
\text { mean }\end{array}$} \\
\hline & & G1 & G2 & G3 & \\
\hline \multirow{6}{*}{ 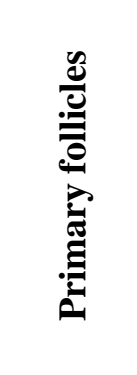 } & \multirow{2}{*}{4} & 74.736 & 57.697 & 65.539 & 64.540 \\
\hline & & \pm 3.065 & \pm 2.167 & \pm 2.654 & $\pm 1.627^{\mathrm{b}}$ \\
\hline & \multirow{2}{*}{6} & 78.288 & 108.593 & 84.941 & 90.607 \\
\hline & & \pm 3.065 & \pm 3.065 & \pm 3.065 & $\pm 1.923^{\mathrm{a}}$ \\
\hline & \multirow{2}{*}{8} & 106.579 & 82.456 & 81.621 & 90.222 \\
\hline & & \pm 3.065 & \pm 3.065 & \pm 3.065 & $\pm 1.923^{\mathrm{a}}$ \\
\hline \multirow{2}{*}{\multicolumn{2}{|c|}{ Overall mean }} & 86.534 & 80.925 & 77.909 & \\
\hline & & $\pm 1.923^{\mathrm{a}}$ & $\pm 1.702^{\mathrm{b}}$ & $\pm 1.830^{b}$ & \\
\hline \multirow{6}{*}{ 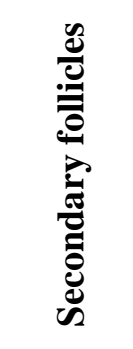 } & \multirow{2}{*}{4} & 28.575 & 24.502 & 35.557 & 29.545 \\
\hline & & \pm 1.072 & \pm 0.853 & \pm 0.928 & $\pm 0.551^{\mathrm{b}}$ \\
\hline & \multirow{2}{*}{6} & 30.371 & 36.240 & 28.425 & 31.679 \\
\hline & & \pm 0.928 & \pm 1.072 & \pm 1.072 & $\pm 0.592^{\mathrm{a}}$ \\
\hline & \multirow{2}{*}{8} & 35.501 & 26.319 & 26.547 & 29.456 \\
\hline & & \pm 1.072 & \pm 1.072 & \pm 1.072 & $\pm 0.618^{\mathrm{b}}$ \\
\hline \multirow{2}{*}{\multicolumn{2}{|c|}{ Overall mean }} & 31.482 & 29.020 & 30.176 & \\
\hline & & $\pm 0.592^{\mathrm{a}}$ & $\pm 0.579^{b}$ & $\pm 0.592^{\mathrm{a}}$ & \\
\hline
\end{tabular}

Overall means in each classification having different letter, differ significantly $(\mathrm{P}<0.05)$

events. In contrast, Abdou et. al. (2007) found that vitamin E supplementation increased $(\mathrm{P}<0.05)$ in the external diameter of sheep skin follicles.

Hynd (2000) reported a direct effect of copper and zinc on follicle function but no evidence implicating the role of vitamin $\mathrm{E}$ in follicular events was found. These findings might explain the increased values of external and internal diameters of G3 compared with the G2. Turbocal forte supplemented to $\mathrm{G} 3$ seems to affect the follicle dimensions via the effect of zinc. Zinc is essential element for the activity of several enzymes 
and especially as an essential component in zinc-finger DNA-binding regulatory proteins of transcription; there are many entry proteins for zinc to play a role in hair and wool growth (Rogers et. Al., 2006).

Table 2. Least square means ( \pm S.E.) for internal diameter of primary and secondary follicles as affected by feed additives and ages.

\begin{tabular}{|c|c|c|c|c|c|}
\hline \multirow{2}{*}{$\begin{array}{l}\text { Follicle } \\
\text { Type }\end{array}$} & \multirow{2}{*}{$\begin{array}{l}\text { Age in } \\
\text { Weeks }\end{array}$} & \multicolumn{3}{|c|}{ Treatment groups } & \multirow{2}{*}{$\begin{array}{c}\text { Overall } \\
\text { mean }\end{array}$} \\
\hline & & G1 & G2 & G3 & \\
\hline \multirow{3}{*}{ 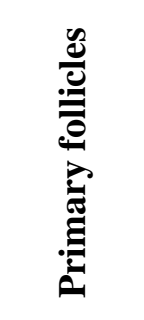 } & 4 & $\begin{array}{l}45.294 \\
\pm 2.444\end{array}$ & $\begin{array}{l}32.341 \\
\pm 1.728\end{array}$ & $\begin{array}{l}41.675 \\
\pm 2.117\end{array}$ & $\begin{array}{l}38.644 \\
\pm 1.244^{\mathrm{c}}\end{array}$ \\
\hline & 6 & $\begin{array}{l}43.729 \\
\pm 2.444\end{array}$ & $\begin{array}{l}58.897 \\
\pm 2.444\end{array}$ & $\begin{array}{l}52.173 \\
\pm 2.444\end{array}$ & $\begin{array}{l}51.600 \\
\pm 1.470^{\mathrm{a}}\end{array}$ \\
\hline & 8 & $\begin{array}{l}52.855 \\
\pm 2.444\end{array}$ & $\begin{array}{l}43.403 \\
\pm 2.444\end{array}$ & $\begin{array}{l}40.267 \\
\pm 2.444\end{array}$ & $\begin{array}{c}45.508 \\
\pm 1.470^{\mathrm{b}}\end{array}$ \\
\hline \multicolumn{2}{|c|}{ Overall mean } & $\begin{array}{r}47.293 \\
\pm 1.470^{a}\end{array}$ & $\begin{array}{c}43.397 \\
\pm 1.302^{b}\end{array}$ & $\begin{array}{c}45.063 \\
\pm 1.399^{a b}\end{array}$ & \\
\hline \multirow{3}{*}{ 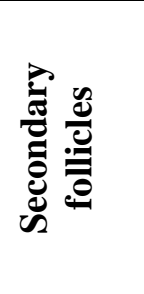 } & 4 & $\begin{array}{l}15.153 \\
\pm 0.705\end{array}$ & $\begin{array}{l}11.436 \\
\pm 0.561\end{array}$ & $\begin{array}{l}19.617 \\
\pm 0.611\end{array}$ & $\begin{array}{c}15.402 \\
\pm 0.363^{\mathrm{b}}\end{array}$ \\
\hline & 6 & $\begin{array}{l}17.516 \\
\pm 0.611\end{array}$ & $\begin{array}{l}19.340 \\
\pm 0.705\end{array}$ & $\begin{array}{l}14.679 \\
\pm 0.705\end{array}$ & $\begin{array}{c}17.178 \\
\pm 0.390^{\mathrm{a}}\end{array}$ \\
\hline & 8 & $\begin{array}{l}17.039 \\
\pm 0.705\end{array}$ & $\begin{array}{l}11.913 \\
\pm 0.705\end{array}$ & $\begin{array}{l}12.704 \\
\pm 0.705\end{array}$ & $\begin{array}{l}13.885 \\
\pm 0.407^{\mathrm{c}}\end{array}$ \\
\hline \multicolumn{2}{|c|}{ Overall mean } & $\begin{array}{r}16.569 \\
\pm 0.390^{a}\end{array}$ & $\begin{array}{r}14.230 \\
\pm 0.381^{b}\end{array}$ & $\begin{array}{c}15.667 \\
\pm 0.390^{\mathrm{a}}\end{array}$ & \\
\hline
\end{tabular}

Overall means in each classification having different letter, differ significantly $(P<0.05)$

Wall thickness, the distance between external and internal diameter, was affected $(\mathrm{P}<0.05)$ by age as a consequence of its effect on the external and internal diameters of the primary and secondary skin follicles (Table 3). Wall thickness of the primary follicles increased gradually with the advanced age and recorded 25.89, 39.00 and $44.71 \mu \mathrm{m}$ at four, six and eight weeks of age, respectively (Table 3). In secondary follicles, wall thickness increased $(\mathrm{P}<0.05)$ only at eight weeks of age, while no significant difference was recorded between the ages of four and six weeks (Table 3).

Oznurlu et. al. (2009) reported that the primary follicles were distinguished with their large diameter and their roots reaching the dermis, whereas secondary follicles were smaller and the roots located superficially. Rabbits had compound hair follicles. Most of the compound hair follicles of 


\section{STUDIES OF SKIN AND ITS COAT CHARACTERISTICS OF RABBITS 111}

the white New Zealand rabbit constituted of a central primary hair follicle and clusters of 2-4 compound follicles surrounding the central primary follicle (Figure 1).

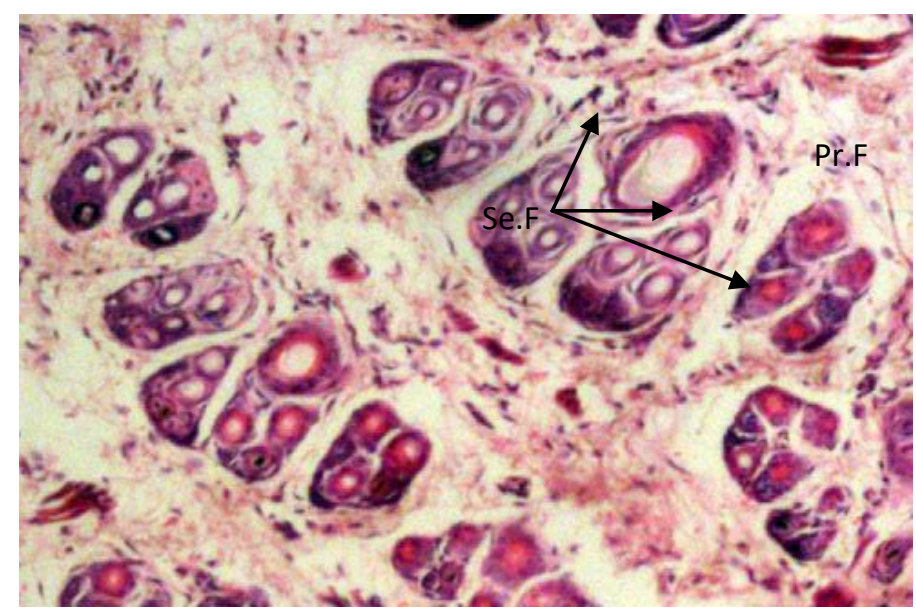

Figure (1): Transverse section of rabbit skin showing hair follicles clusters. (Hx.\&E. X100)

Table 3. Least square means ( \pm S.E.) for wall thickness of primary and secondary follicles as affected by feed additives and ages.

\begin{tabular}{|c|c|c|c|c|c|}
\hline \multirow{2}{*}{$\begin{array}{c}\text { Follicle } \\
\text { Type }\end{array}$} & \multirow{2}{*}{$\begin{array}{l}\text { Age in } \\
\text { Weeks }\end{array}$} & \multicolumn{3}{|c|}{ Treatment groups } & \multirow{2}{*}{$\begin{array}{c}\text { Overall } \\
\text { mean }\end{array}$} \\
\hline & & G1 & G2 & G3 & \\
\hline \multirow{3}{*}{ 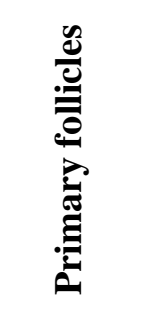 } & 4 & $\begin{array}{l}29.442 \\
\pm 1.400\end{array}$ & $\begin{array}{l}25.355 \\
\pm 0.990\end{array}$ & $\begin{array}{l}23.865 \\
\pm 1.212\end{array}$ & $\begin{array}{r}25.895 \\
\pm 0.754^{\mathrm{c}}\end{array}$ \\
\hline & 6 & $\begin{array}{l}34.558 \\
\pm 1.400\end{array}$ & $\begin{array}{l}49.696 \\
\pm 1.400\end{array}$ & $\begin{array}{l}32.766 \\
\pm 1.400\end{array}$ & $\begin{array}{c}39.006 \\
\pm 0.891^{b}\end{array}$ \\
\hline & 8 & $\begin{array}{l}53.724 \\
\pm 1.400\end{array}$ & $\begin{array}{l}39.061 \\
\pm 1.400\end{array}$ & $\begin{array}{l}41.355 \\
\pm 1.400\end{array}$ & $\begin{array}{l}44.713 \\
\pm 0.891^{\mathrm{a}}\end{array}$ \\
\hline \multicolumn{2}{|c|}{ Overall mean } & $\begin{array}{c}39.242 \\
\pm 0.891^{a}\end{array}$ & $\begin{array}{c}37.527 \\
\pm \mathbf{0 . 7 8 9}\end{array}$ & $\begin{array}{r}32.846 \\
\pm 0.848^{c}\end{array}$ & \\
\hline \multirow{3}{*}{ 莺 } & 4 & $\begin{array}{l}13.423 \\
\pm 0.683\end{array}$ & $\begin{array}{l}13.064 \\
\pm 0.544\end{array}$ & $\begin{array}{l}15.940 \\
\pm 0.591\end{array}$ & $\begin{array}{c}14.142 \\
\pm 0.351^{\mathrm{b}}\end{array}$ \\
\hline & 6 & $\begin{array}{l}12.854 \\
\pm 0.591\end{array}$ & $\begin{array}{l}16.901 \\
\pm 0.683\end{array}$ & $\begin{array}{l}13.746 \\
\pm 0.683\end{array}$ & $\begin{array}{c}14.500 \\
\pm 0.377^{\mathrm{b}}\end{array}$ \\
\hline & 8 & $\begin{array}{l}18.460 \\
\pm 0.683\end{array}$ & $\begin{array}{l}14.406 \\
\pm 0.683\end{array}$ & $\begin{array}{r}13.842 \\
\pm 0.683\end{array}$ & $\begin{array}{r}15.570 \\
\pm 0.394^{\mathrm{a}}\end{array}$ \\
\hline
\end{tabular}


TAHA et al.

\begin{tabular}{cccc}
\hline \multirow{2}{*}{ Overall mean } & 14.912 & 14.790 & 14.510 \\
& $\pm 0.377^{\mathrm{a}}$ & $\pm 0.369^{\mathrm{a}}$ & $\pm 0.377^{\mathrm{a}}$ \\
\hline
\end{tabular}

Overall means in each classification having different letter, differ significantly $(P<0.05)$

The effect of feed additives on the wall thickness was obvious in the primary follicles where the wall thickness declined $(\mathrm{P}<0.05)$ in $\mathrm{G} 2$ and $\mathrm{G} 3$ compared with G1. In contrast, Abdou et. al. (2007) reported wider $(\mathrm{P}<0.05)$ wall thickness of the primary follicles in rams supplemented with vitamin E. On the other hand, feed additives did not affect the wall thickness of the secondary follicles (Table 3).

Changes in fiber diameter as affected by age or feed additives were presented in (Table 4). These changes followed the same sequence of internal diameter of both follicle types (Table 2). In primary follicles, fiber diameter increased at six weeks of age compared with that of four weeks of age then decreased to intermediate value at the age of eight weeks $(\mathrm{P}<0.05)$. In secondary follicles, fiber diameter increased at six weeks of age to its maximum then it decreased to its lowest value at the age of eight weeks $(\mathrm{P}<0.05)$.

According to Schlolaut (1985), up to the end of puberty at 4 to 5 months of age; three types of hair were distinguished. Infant hair tell the forth to fifth week of age, young animal hair from sixth to eighth week of age and juvenile at ninth to seventeenth week of age. Each phase is terminated by moulting. This indicated shedding might explain the reduction in fiber diameter at eight weeks of age.

Rabbits in $\mathrm{G} 2$ had the lowest $(\mathrm{P}<0.05)$ diameter values of fibres produced from both primary and secondary follicles compared with the other groups. Results indicated that the changes in fiber diameter happened as a consequence to the changes in follicles internal diameter.

Similar results were reported by Abdou et. al. (2007) who found a significant decrease in wool fiber diameter in sheep supplemented with vitamin $\mathrm{E}$. G3 had a higher fiber diameter than $\mathrm{G} 2$. It is possibly due to the effect of zinc in Turbocal. Hynd (2000) reported that zinc has a direct effect on follicle function, independent on effect of feed intake and is essential for normal keratinization of fibers.

Secondary to primary follicles ratio increased $(\mathrm{P}<0.05)$ at six weeks of age then settled to the age of eight weeks (Table 5). No significant effect of feed additives was found on the ratio of secondary to primary follicles. Atlee $e t$. al. (1997) reported that the fiber quality of wool-producing species is often expressed in terms of the secondary to primary hair ratio (S/P ratio).

Changes in the percentage of fine fibers with a diameter less than or equal thirty micrometer and prickle factor, that represents the percentage of 


\section{STUDIES OF SKIN AND ITS COAT CHARACTERISTICS OF RABBITS 113}

fibers with a diameter greater than thirty micrometers, at different ages of study were illustrated in Figure (2). The percentage of fibers with diameter less than 30 micrometers decreased with age advance $(\mathrm{P}<0.05)$ where it was

Table 4. Least square means $( \pm$ S.E. $)$ for fiber diameter of primary and secondary follicles as affected by feed additives and ages.

\begin{tabular}{|c|c|c|c|c|c|}
\hline \multirow{2}{*}{$\begin{array}{c}\text { Follicle } \\
\text { Type }\end{array}$} & \multirow{2}{*}{$\begin{array}{l}\text { Age in } \\
\text { Weeks }\end{array}$} & \multicolumn{3}{|c|}{ Treatment groups } & \multirow{2}{*}{$\begin{array}{c}\text { Overall } \\
\text { mean }\end{array}$} \\
\hline & & G1 & G2 & G3 & \\
\hline \multirow{6}{*}{ 㲵 } & \multirow{2}{*}{4} & 38.697 & 26.711 & 34.275 & 32.193 \\
\hline & & \pm 2.227 & \pm 1.575 & \pm 1.929 & $\pm 1.139^{\mathrm{c}}$ \\
\hline & \multirow{2}{*}{6} & 34.457 & 49.955 & 44.410 & 42.941 \\
\hline & & \pm 2.227 & \pm 2.227 & \pm 2.227 & $\pm 1.346^{\mathrm{a}}$ \\
\hline & \multirow{2}{*}{8} & 44.914 & 35.090 & 33.566 & 37.857 \\
\hline & & \pm 2.227 & \pm 2.227 & \pm 2.227 & $\pm 1.346^{\mathrm{b}}$ \\
\hline \multirow{2}{*}{\multicolumn{2}{|c|}{ Overall mean }} & 39.356 & 35.984 & 37.650 & \\
\hline & & $\pm 1.346^{\mathrm{a}}$ & $\pm 1.192^{\circ}$ & $\pm 1.281^{\mathrm{ab}}$ & \\
\hline \multirow{6}{*}{ 莺 } & \multirow{2}{*}{4} & 9.964 & 7.470 & 14.578 & 10.671 \\
\hline & & \pm 0.682 & \pm 0.543 & \pm 0.59 & $\pm 0.351^{\mathrm{b}}$ \\
\hline & \multirow{2}{*}{6} & 11.475 & 14.883 & 9.159 & 11.839 \\
\hline & & \pm 0.590 & \pm 0.682 & \pm 0.682 & $\pm 0.377^{\mathrm{a}}$ \\
\hline & \multirow{2}{*}{8} & 10.953 & 7.854 & 8.450 & 9.086 \\
\hline & & \pm 0.682 & \pm 0.682 & \pm 0.682 & $\pm 0.393^{\mathrm{c}}$ \\
\hline \multirow{2}{*}{\multicolumn{2}{|c|}{ Overall mean }} & 10.797 & 10.069 & 10.792 & \\
\hline & & $\pm 0.377^{a}$ & $\pm 0.369^{\circ}$ & $\pm 0.377^{a}$ & \\
\hline
\end{tabular}

Overall means in each classification having different letter, differ significantly $(P<0.05)$

Table 5. Least square means ( \pm S.E.) for S/P ratio as affected by feed additives and ages.

\begin{tabular}{crccc}
\hline \multirow{2}{*}{ Age in Weeks } & \multicolumn{3}{c}{ Treatment groups } & $\begin{array}{c}\text { Overall } \\
\text { mean }\end{array}$ \\
\cline { 2 - 4 } & \multicolumn{1}{c}{ G1 } & G2 & G3 & 7.094 \\
\multirow{2}{*}{4} & 5.267 & 7.728 & 8.288 & $\pm 0.573^{\mathrm{b}}$ \\
& \pm 0.908 & \pm 1.015 & \pm 1.049 & 10.967 \\
6 & 10.818 & 10.974 & 11.110 & $\pm 0.655^{\mathrm{a}}$ \\
& \pm 1.225 & \pm 1.127 & \pm 1.049 & 10.476 \\
\multirow{2}{*}{8} & 11.454 & 9.333 & 10.642 & $\pm 0.708^{\mathrm{a}}$ \\
\hline \multirow{2}{*}{ Overall mean } & \pm 1.225 & \pm 1.354 & \pm 1.086 & \\
\hline
\end{tabular}

Overall means in each classification having different letter, differ significantly $(P<0.05)$ 
97.73, 95.32 and $95.33(\%)$ of the rabbit fur at four, six and eight weeks of age, respectively. In contrast, the prickle factor Increased $(\mathrm{P}<0.05)$ with age advance from $2.27 \%$ at four weeks to 4.68 and $4.67(\%)$ at six and eight weeks, respectively (Figure 2).

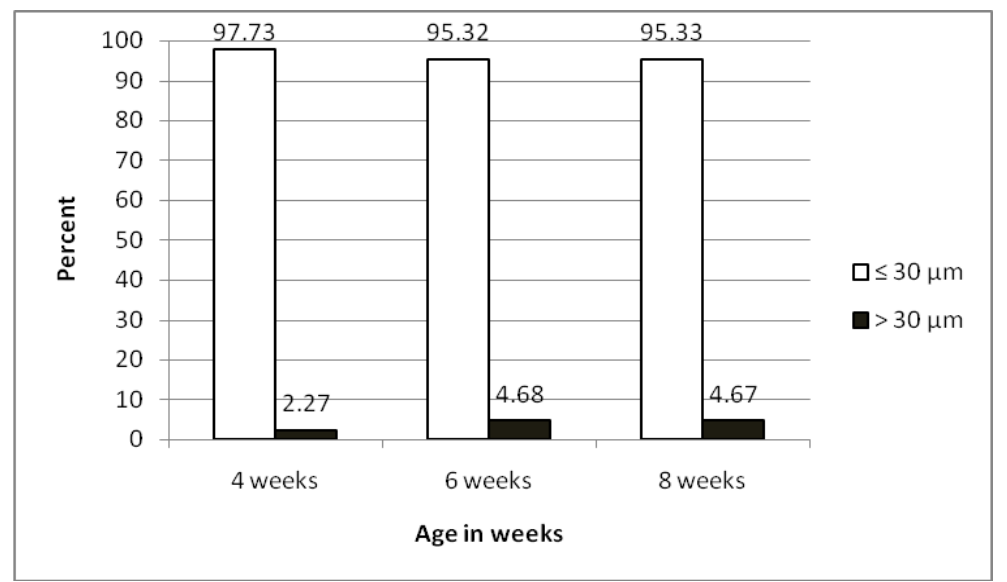

Figure 2. Percentage of fibers with diameter $\leq 30 \mu \mathrm{m}$ and those $>30 \mu \mathrm{m}$ at four, Six and eight weeks of age in rabbit fur.

No significant differences were found between treatments in the percentages of fine fibers and prickle factor. However, G3 had a slightly lower percentage of fine fibers and a higher prickle factor compared with G1 and G2 as presented in Figure (3).

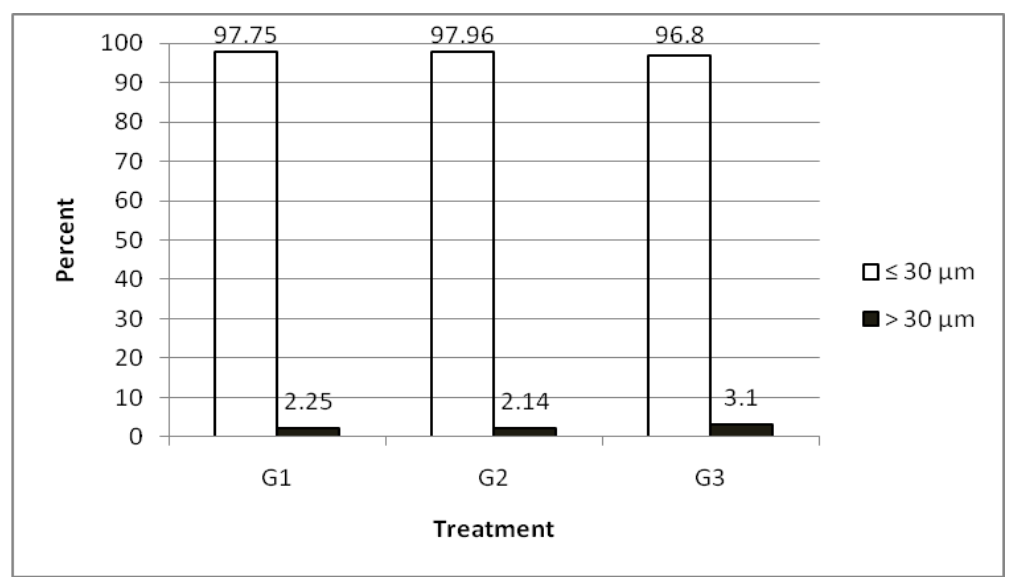

Figure 3. Percentage of fibers with diameter $\leq 30 \mu \mathrm{m}$ and those $>30 \mu \mathrm{m}$ in rabbit fur as affected with different treatments. 


\section{STUDIES OF SKIN AND ITS COAT CHARACTERISTICS OF RABBITS 115}

The prickle factor measurement was originally devised to quantify the number of fibers with diameter more than $30 \mu \mathrm{m}$. These coarse fibers are capable of causing irritation to humans when worn next to the skin (Naylor et al., 1992).

Rogers et. al. (2006) reported prickle factor values of 3.5 and $11.3(\%)$ for genetically furred and furless rabbits, respectively. According to ASMT (2002), prickle factor may assist to distinguish between fine fur fibers produced in secondary follicles and relatively coarse guard hair produced in primary follicles. Moore et al. (1998) reported a negative but high correlation between fiber diameter and follicle density was previously illustrated and selection efforts on wool-producing activities of skin would predominantly affect follicle density and fiber characteristics.

Fibers were visually classified to coarse and fine fibers; the average fiber length of coarse and fine fibers as affected by age and treatments was shown in Table 6. It could be easily noticed that fiber length declined $(\mathrm{P}<0.05)$ at six week of age then increased again at the age of eight weeks in opposite trend to the average fiber diameter (Table 4).

Table (8): Least square means ( \pm S.E.) for Fiber Length $(\mathrm{cm})$ as affected by feed additives and ages.

\begin{tabular}{|c|c|c|c|c|c|}
\hline \multirow{2}{*}{$\begin{array}{l}\text { Age in } \\
\text { Weeks }\end{array}$} & \multirow{2}{*}{$\begin{array}{l}\text { Fiber } \\
\text { type }\end{array}$} & \multicolumn{3}{|c|}{ Treatment groups } & \multirow{2}{*}{ Overall of age } \\
\hline & & G1 & G2 & G3 & \\
\hline \multirow{4}{*}{4} & \multirow{2}{*}{ Coarse } & 2.076 & 2.456 & 2.445 & \multirow{4}{*}{$\begin{array}{c}2.221 \\
\pm 0.046^{\mathrm{a}}\end{array}$} \\
\hline & & \pm 0.133 & \pm 0.108 & \pm 0.110 & \\
\hline & \multirow{2}{*}{ Fine } & 1.476 & 2.332 & 2.541 & \\
\hline & & \pm 0.098 & \pm 0.115 & \pm 0.113 & \\
\hline \multirow{4}{*}{6} & \multirow{2}{*}{ Coarse } & 1.829 & 1.933 & 2.781 & \multirow{4}{*}{$\begin{array}{c}1.836 \\
\pm 0.052^{\mathrm{b}}\end{array}$} \\
\hline & & \pm 0.117 & \pm 0.158 & \pm 0.184 & \\
\hline & \multirow{2}{*}{ Fine } & 1.248 & 1.662 & 1.561 & \\
\hline & & \pm 0.106 & \pm 0.091 & \pm 0.087 & \\
\hline \multirow{4}{*}{8} & \multirow{2}{*}{ Coarse } & 2.292 & 2.605 & 3.290 & \multirow{4}{*}{$\begin{array}{c}2.349 \\
\pm 0.053^{\mathrm{a}}\end{array}$} \\
\hline & & \pm 0.120 & \pm 0.148 & \pm 0.193 & \\
\hline & \multirow{2}{*}{ Fine } & 1.794 & 2.027 & 2.084 & \\
\hline & & \pm 0.105 & \pm 0.093 & \pm 0.086 & \\
\hline \multicolumn{2}{|c|}{$\begin{array}{l}\text { Over all of } \\
\text { treatment }\end{array}$} & $\begin{array}{c}1.786 \\
\pm 0.046^{b}\end{array}$ & $\begin{array}{c}2.169 \\
\pm 0.049^{a}\end{array}$ & $\begin{array}{c}2.450 \\
\pm 0.055^{a}\end{array}$ & \\
\hline
\end{tabular}

Fiber growth is accumulation of longitudinal growth in length and cross sectional growth in diameter. It seems that there is a critical growth period at the age of six weeks that inhibited the longitudinal fiber growth while it 
stimulated the cross sectional fiber growth. Schlolaut (1985) reported shorter hair fiber length of 3-4 $\mathrm{cm}$ of the normal rabbits compared with Angora rabbits where fiber length ranges between 6 to $11 \mathrm{~cm}$, he referred this difference to the prolonged active phase of the skin follicles of Angora rabbit. Fiber length of $\mathrm{G} 2$ and $\mathrm{G} 3$ was higher $(\mathrm{P}<0.05)$ than the fiber length of $\mathrm{G} 1$.

In coincidence with the results of Tao (1994), coarse fibers had higher length than fine fibers (Table 8). Von Bergen (1963) stated that the rabbit's coat consists of two main types of fiber, relatively coarse guard hairs and fine fur (undercoat) fibers. Lebas et al. (1997) reported that quite apart from age of slaughtering and raising under poor conditions, the long coarse hairs in the coat that easily break and the unequal growth of the zones with shorter or looser hairs are two major defects that low pricing make rabbit fur. According to Rogers et al., (2006), the guard hairs vary considerably in thickness and length but are generally longer than the fur fibers and thus project above the undercoat.

Conclusively, age has a significant effect on the primary and secondary skin follicles characteristics of the growing New Zealand White rabbits especially at the age of six weeks where a declined fiber length and increased fiber diameter were observed. Fine fibers consisted the majority of fur of the growing New Zealand White rabbits while the coarse fibers was longer than fine ones $(\mathrm{P}<0.05)$.

Supplementation with vitamin $\mathrm{E}$ or zinc increased the average fiber length of the growing New Zealand White rabbits but they did not increase the fiber diameter. This may encourage using these kinds of supplementations to increase the fiber yield without affecting the fiber diameter.

\section{REFERENCES}

Abdou, A. S. A.; Hekal, S. A. A. and Taha, E. A. (2007). Impact of vitamin $\mathrm{A}$ and vitamin $\mathrm{E}$ supplementation on some wool and skin characteristics of Barki sheep. Egyptian J. Pasic Appl. Physiol., 6 (2): 375-390.

Allain, D. (2007). Fleece and fibre measurements in angora goats and angora rabbits. http :// www .macaulay. ac.uk leuropeanfibre leffnnew lda .htm.

American Society for Testing and Materials Standards (ASTM). (2002). Designation: D2816. Standard test method for cashmere coarse-hair content in cashmere. Annual Book of ASTM Standards, Sec.7. Vol.7. (1)692-694.

Anandan, S; Deyu, A. and Deb, M. (1996). Effect of zinc and copper supplementation on wool production in German Angora rabbits. Indian J. Anim. Nutrition. 15 (3): 216-217. 
Atlee, B. A.; Stannard, A. A.; Fowler, M. E.; Willemse, T.; Ihrke, P. J. and Olivry, T. (1997). The histology of normal llama skin. Vet. Dermatol., 8: 165-176.

Barker, J. R. (1958). Principles of biological technique. London, Meunchen, New York. John Wiley. Bancroft. J. D.

Drury, R. A. P. and Wallington, E. A. (1980). Carlton's Histological Technique. 4th Ed. Oxford, New York, Toronto, Oxford University Press.

Duncan, D. B. (1955). Multiple range and multiple F test. Biometrics, 11:1-12.

Hunt, C. E.; and Harrington, D. D. (1974). Nutrition and Nutritional Diseases of the Rabbits. In: (Eds: Weisbrath, S. H; Flatt, R. E. and Kraus, A. L.) The Biology of the Laboratory Rabbits. Academic Press. New York. 403-433.

Hynd, P. I. (2000). The nutritional biochemistry of wool and hair follicles. Animal Science, Vol. 70 (2):181-195

Lanszki, J.; Thebaul, R.; Allain, D.; Szendro, Z. and Eiben, C. (2001). The effects of melatonin treatment on wool production and hair follicle cycle in Angora rabbits. Anim. Res., 50: 79-89.

Lebas, F. (2000). Vitamins in rabbit nutrition: Literature review and recommendations. World Rabbit Science., 8 (4): 185-192.

Lebas, F.; Coudert, P.; de Rochambeau, H. and Thébault, R. G. (1997). The rabbit - Husbandry, health and production. FAO - food and agriculture organization of the united nations. Rome, FAO Animal Production and Health Series No. 21. 1997.

Monteiro-Riviere, N. A. and Stinson, A. W. (1998). Integument. In: Textbook of Veterinary Histology, (Eds. Delmann, H.D. and Eurell, J.A.) Lippincot Williams and Wilkins, Baltimore, Maryland, USA., ISBN: 978-0-7817-4148-4, pp: 303-332.

Moore, G. P. M.; Jackson, N.; Isaacs, K. and Brown, G. (1998). Pattern and morphogenesis in skin. J. Theory Biology, 191: 87-94.

Naylor, G. R. S.; Veitch, C. J.; Mayfield, R. J. and Kettlewell, R.(1992). Fabric evoked prickle of some wool fabrics. Textile Research J., 62:487493.

Oznurlu, Y; Celik, I; Sur, E; Telatar, T and Ozparlak, H (2009). Comparative Skin Histology of the New Zealand White and Angora Rabbits: Histometrical and Immunohistochemical Evaluations. Journal of Animal and Veterinary Advances, 8 (9): 1694-1701.

Paus, R.; Stenn K. S. and Link, R.E. (1990). Telogen skin contains an inhibitor of hair growth. British J. Dermatology, 122: 777-784. 
Rogers, A. D; Lupton, C. J. and Lukefahr, S. D. (2006). Fiber production and properties in genetically furred and furless rabbits. J. Anim. Sci., 84:2566-2574.

SAS (2007): Statistical analysis System. Stat-user's guid. Release 9.1.3. SAS Institute. Cary, NC, USA.

Schlolaut, W. (1985). A compendium of rabbit production appropriate for conditions in developing countries. Schriftenreihe der GTZ (Germany, F.R.), no. 168, 169. Eschborn, 1985.

Shaw, N. A; Dickey, H. C; Brugman, H. H; Blamberg, D. L. and Witter, J.F. (1974). Zinc deficiency in female rabbits. Laboratory Animals, 8: 1-7.

Snedecor, G. W. and Cochran, W. C. (1982). Statistical Methods. $6^{\text {th }}$ Edition, Iowa State University Press, Ames USA.

Soma, T., M; Suzuki, O. J; Takahashi, T. and Hibino, T. (1998). Analysis of apoptotic cell death in human hair follicles in vivo and in vitro. $J$. Invest. Dermatology, 111: 948-954.

Stenn, K.S. and R. Paus, (2001). Controls of hair follicle cycling. Physiol. Rev., 81: 449-494.

Tao, Y.R. (1992).New technology of Rex rabbit raising. Shangai Sceine and Technology Publications, 6-14.

Tao, Y.R. (1994). Studies on the quality of Rex rabbit fur. World Rabbit Science. 2(1): 21-24.

Von Bergen, W. (1963). in The Wool Handbook. Volume 1. Chapter 5. Specialty hair fibers. Interscience Publishers, John Wiley \& Sons, New York, NY. Pages: 432-445.

Yamani, B. and Stein, S. (1989). Abortion, stillbirth, neonatal death nutritional myodegeneration in rabbit breeding colony. J. Am. Vet. Med. Assoc., 194: 561-562.

\section{دراسات لبعض صفات الجلد و غطاء الجسم و علاقتها بالإضافات الغذائية في الأرانب النامية \\ عماد الاسلام احمد طه، سامية هيكل، نجلاء سالم بدوي.

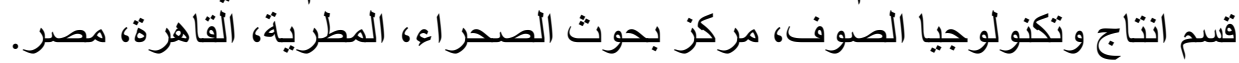

$$
\begin{aligned}
& \text { اجريت هذه التجربة في محطة بحوث مريوط التابعة لمركز بحوث الصحر اء }
\end{aligned}
$$

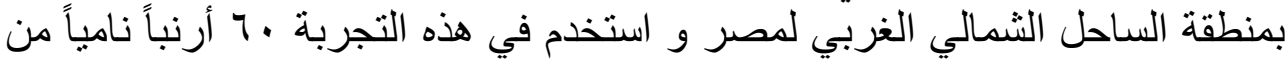

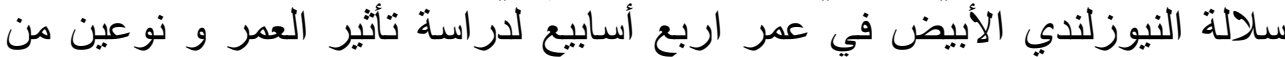




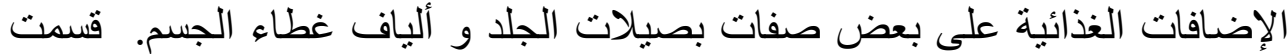

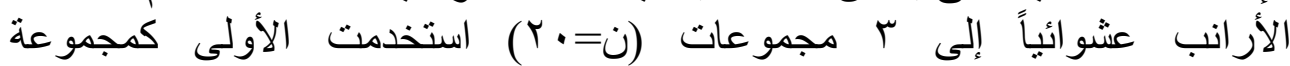

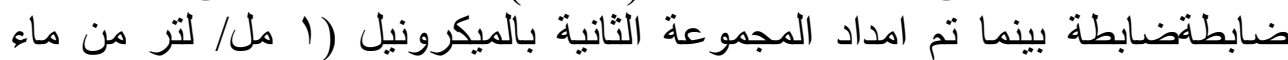

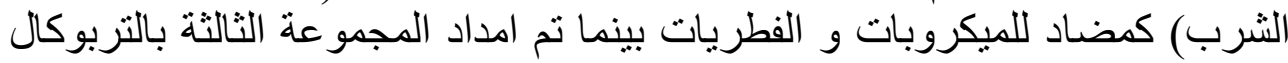

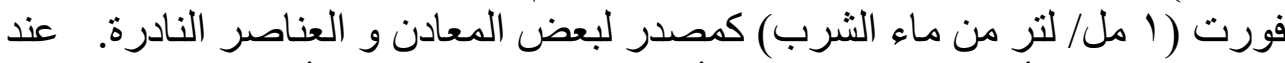

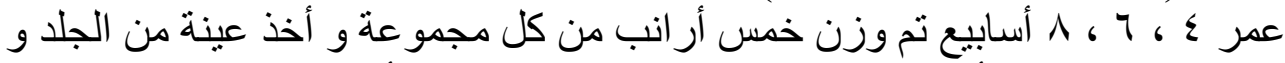

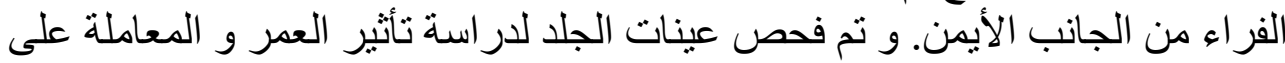
خواص البصيلات و قطر الألياف.

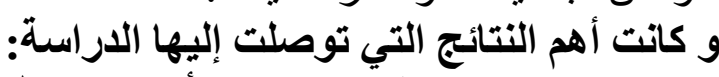

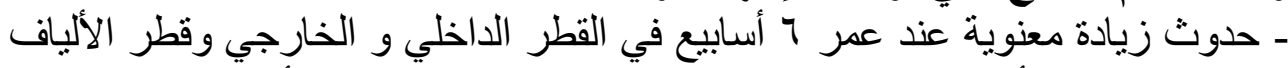
في البصيلات الأولية و الثانوية وعية في نسبة البصيلات الثيات الثانوية إلى الأولية.

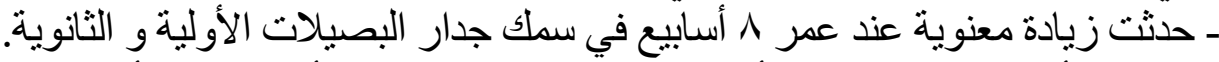

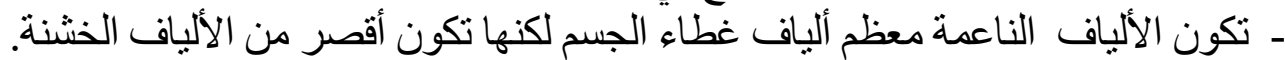

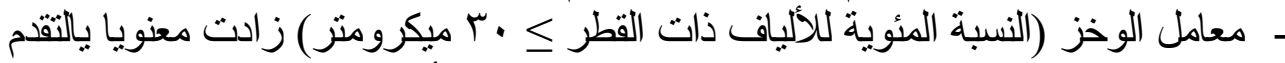

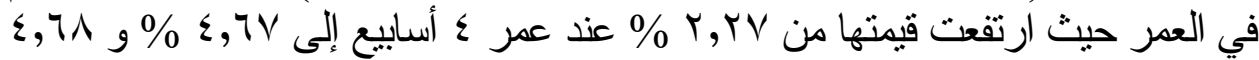

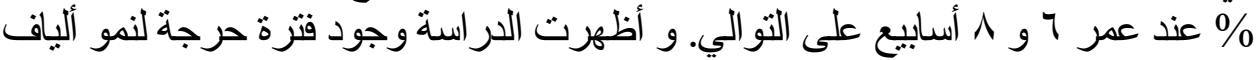

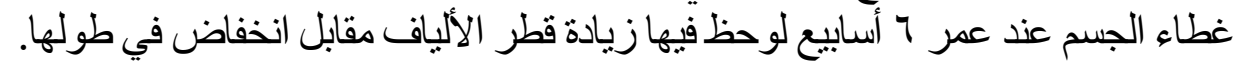

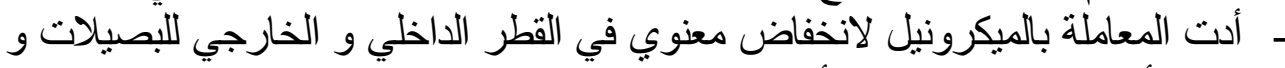

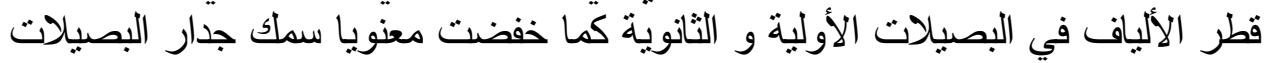

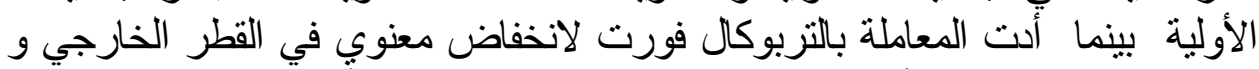

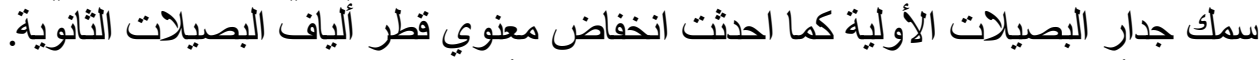

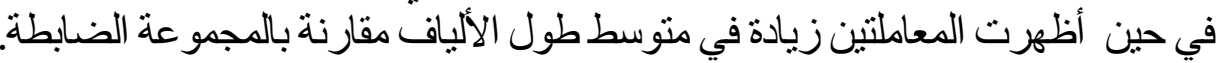

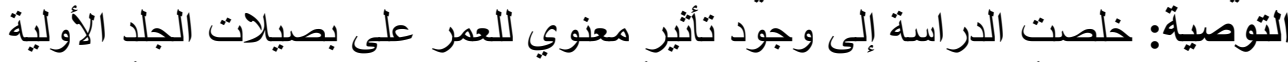

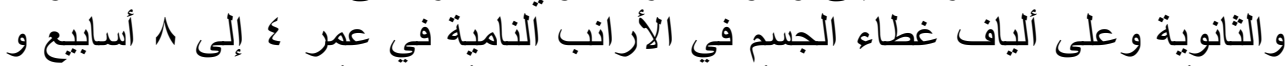

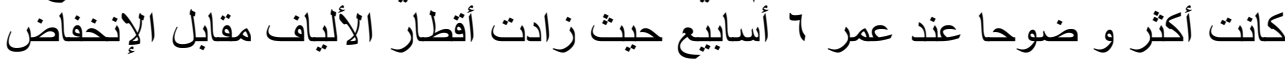

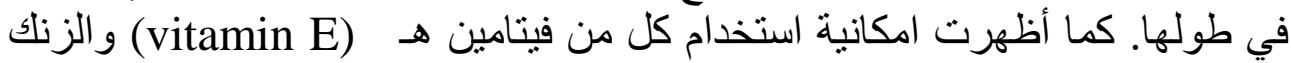
(Zn)

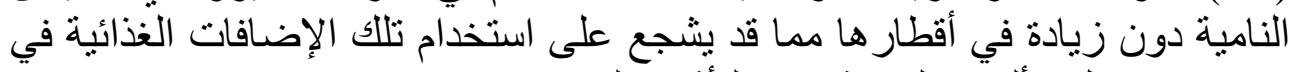
زيادة محصول الألياف الناتجة دون التأثير على نعومتها. 